\section{Spotlight on the August 17 Issue}

Robert A. Gross, MD, PhD, FAAN

Editor-in-Chief, Neurology ${ }^{\circledR}$

\section{Primary progressive nonfluent aphasia}

(6)

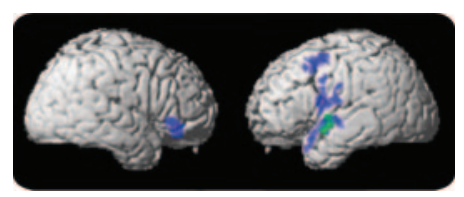

\section{Gunawardena and} colleagues studied 16 consecutively examined patients with progressive nonfluent aphasia (PNFA)

and found that nonfluent speech difficulties with grammatical processing were associated with left inferior frontal and anterior-superior temporal disease.

In the Hu et al. study, 12 patients with logopenic progressive aphasia and 6 patients with PNFA had neuropathologic findings consistent with Alzheimer disease. Combining neuropsychological testing with MRI analysis can improve underlying pathology in nonfluent forms of primary progressive aphasia (PPA).

Rohrer et al. conducted a clinical and neurolinguistic crosssectional analysis of a cohort of 24 patients with nonfluent PPA. Their findings provide a rationale for further longitudinal studies with pathologic correlation.

See p. 588, p. 595, p. 603

Editorial quote from Bradford Dickerson: "Ultimately, research of the sort in this trio of articles will shed new light on the forms of language dysfunction that may occur in PPA and their biological basis."

See p. 582

Juvenile ALS with basophilic inclusions is a FUS proteinopathy with FUS mutations

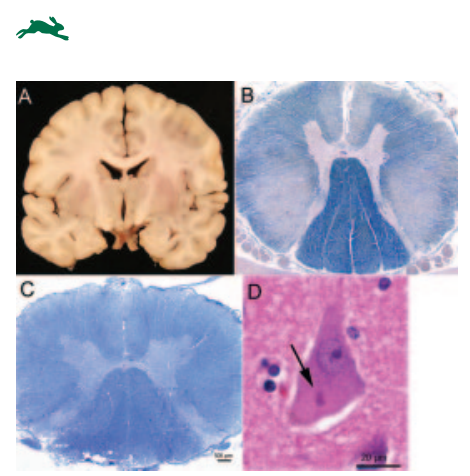

Four neuropathologically identified patients with juvenile amyotrophic lateral sclerosis (ALS) with basophilic inclusions were studied to test whether specific RNA binding protein pathology defines this type of ALS. The findings are an important

contribution to the nosology of ALS.

See p. 611; Editorial, p. 584
AMERICAN ACADEMY OF NEUROLOGY。

Lithium carbonate in amyotrophic lateral sclerosis: Lack of efficacy in a dose-finding trial

$\rightarrow$ 金

This single-blind, randomized trial included 171 patients, 87 randomized to the therapeutic group and 84 to the subtherapeutic group. It provides Class II evidence that therapeutic vs subtherapeutic lithium carbonate did not differ in the primary outcome of efficacy (survival/loss of autonomy) in ALS. See p. 619, Editorial 586

\section{Do-not-resuscitate orders and predictive models after intracerebral hemorrhage \\ ar}

The investigators used data from Texas and California to compare real outcome with that predicted by published outcome models. The authors found that the models perform very differently when patients do or do not have do-not-resuscitate orders.

See p. 626

Severe neonatal episodic laryngospasm due to de novo SCN4A mutations: A new treatable disorder

\section{[D]}

The authors describe neonatal life-threatening features of myotonia caused by de novo mutations in the muscle sodium channel gene SCN4A. Severe neonatal episodic laryngospasm is a new phenotype caused by a sodium channelopathy that can be alleviated by channel blockers.

See p. 641

RESIDENT \& FELLOW SECTION

Clinical Reasoning: A 75-year-old woman with visual disturbances and unilateral ataxia 向

A 75-year-old woman with a relapsing unilateral brainstem syndrome after 9 years was found to have elevated antiGADAbs and polyendocrinopathy. Less likely diagnostic possibilities included recurrent demyelination, stroke, Bickerstaff or viral brainstem encephalitis.

See p. e29

NB: "Acetylcholine in the cerebral cortex. .." and other Clinical Implications for Neuroscience Research papers.

See p. 659

Podcasts can be accessed at www.neurology.org 


\title{
Neurology
}

\author{
In Focus: Spotlight on the August 17 Issue \\ Robert A. Gross \\ Neurology 2010;75;581 \\ DOI 10.1212/WNL.0b013e3181ee6643
}

This information is current as of August 16, 2010

Updated Information \&

Services

Permissions \& Licensing

Reprints including high resolution figures, can be found at: http://n.neurology.org/content/75/7/581.full

Information about reproducing this article in parts (figures,tables) or in its entirety can be found online at:

http://www.neurology.org/about/about_the_journal\#permissions

Information about ordering reprints can be found online:

http://n.neurology.org/subscribers/advertise

Neurology ${ }^{\circledR}$ is the official journal of the American Academy of Neurology. Published continuously since 1951, it is now a weekly with 48 issues per year. Copyright. All rights reserved. Print ISSN: 0028-3878. Online ISSN: 1526-632X.

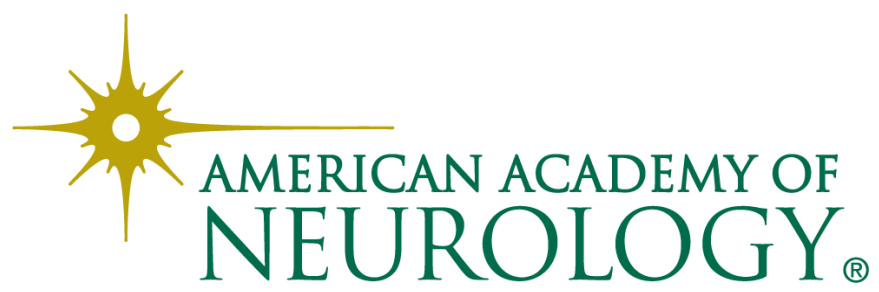

